\title{
Application of Li-, Mg-, Ba-, Sr-, Ca-, and Sn-doped ceria for solar-driven thermochemical conversion of carbon dioxide
}

\author{
Gorakshnath Takalkar ${ }^{1}$, Rahul R. Bhosale ${ }^{1, \star}$ (D), Suliman Rashid ${ }^{1}$, Fares AlMomani ${ }^{1}$, \\ Rana Abdul Shakoor ${ }^{2}$, and Abdullah Al Ashraf ${ }^{2}$ \\ ${ }^{1}$ Department of Chemical Engineering, College of Engineering, Qatar University, P. O. Box 2713, Doha, Qatar \\ ${ }^{2}$ Center for Advanced Materials (CAM), Qatar University, P.O. Box 2713, Doha, Qatar
}

Received: 29 January 2020

Accepted: 26 May 2020

Published online:

13 June 2020

(C) The Author(s) 2020

\begin{abstract}
The redox reactivity of the $\mathrm{Li}_{-}, \mathrm{Mg}-$, $\mathrm{Ca}-, \mathrm{Sr}-, \mathrm{Ba}-$, and $\mathrm{Sn}$-doped ceria $\left(\mathrm{Ce}_{0.9}\right.$ $\mathrm{A}_{0.1} \mathrm{O}_{2-\delta}$ ) toward thermochemical $\mathrm{CO}_{2}$ splitting is investigated. Proposed $\mathrm{Ce}_{0.9} \mathrm{~A}_{0.1} \mathrm{O}_{2-\delta}$ materials are prepared via co-precipitation of the hydroxide technique. The composition, morphology, and the average particle size of the $\mathrm{Ce}_{0.9} \mathrm{~A}_{0.1} \mathrm{O}_{2-\delta}$ materials are determined by using suitable characterization methods. By utilizing a thermogravimetric analyzer setup, the long-term redox performance of each $\mathrm{Ce}_{0.9} \mathrm{~A}_{0.1} \mathrm{O}_{2-\delta}$ material is estimated. The results obtained indicate that all the $\mathrm{Ce}_{0.9} \mathrm{~A}_{0.1} \mathrm{O}_{2-\delta}$ materials are able to produce steady amounts of $\mathrm{O}_{2}$ and $\mathrm{CO}$ from cycle 4 to cycle 10 . Based on the average $n_{\mathrm{O}_{2}}$ released and $n_{\mathrm{CO}}$ produced, the $\mathrm{Ce}_{0.899} \mathrm{Sn}_{0.102} \mathrm{O}_{2.002}$ and $\mathrm{Ce}_{0.895} \mathrm{Ca}_{0.099} \mathrm{O}_{1.889}$ are observed to be the top and bottom-most choices. When compared with the $\mathrm{CeO}_{2}$ material, all $\mathrm{Ce}_{0.9} \mathrm{~A}_{0.1} \mathrm{O}_{2-\delta}$ materials showed elevated levels of $\mathrm{O}_{2}$ release and $\mathrm{CO}$ production.
\end{abstract}

\section{Introduction}

The rise in the world's population is one of the primary reasons for the increase in the consumption of energy. As per the sources, the energy requirement of the world will increase up to 30 TW by 2050 [1]. More than $80 \%$ of the current energy necessity has been fulfilled by utilizing fossil fuels such as natural gas, oil, and coal. This excessive use of fossil fuels increased the atmospheric concentration of carbon dioxide. Plenty of research is currently focused on capturing the $\mathrm{CO}_{2}$ from the industrial off-gases and sequestering it in the possible storage locations [2-5]. The utilization of $\mathrm{CO}_{2}$ for the manufacturing of valuable products is a possible alternative to deal with $\mathrm{CO}_{2}$-related issues. One of the options is to convert $\mathrm{CO}_{2}$ into syngas, which can be further utilized in the Fischer Tropsch process [6].

Two-step metal oxide (MO)-based solar thermochemical cycle (STC) is one of the possible ways for the production of syngas via $\mathrm{H}_{2} \mathrm{O}$ (WS) and $\mathrm{CO}_{2}$ splitting (CS) [7-9]. The requirement of lower

Address correspondence to E-mail: rahul.bhosale@qu.edu.qa; rrbhosle1985@gmail.com 
operating temperatures compared to direct thermolysis and utilization of the same MO in multiple cycles are some of the major advantages associated with the STCs. Besides, the $\mathrm{H}_{2} / \mathrm{CO}$ and $\mathrm{O}_{2}$ are produced in two different steps; hence, the need for a cost-intensive separation method is avoided. Previously, zinc oxide $[10,11]$, tin oxide [12, 13], iron oxide [14, 15], ceria and doped ceria [16, 17], ferrites [18-22], perovskites [23-27], and others [28-31] have been considered for the STCs. Among these MOs, ceria-based oxides showed long-term stability and faster reaction kinetics for multiple STCs. In general, the ceria-based oxide is thermally reduced by releasing lattice $\mathrm{O}_{2}$ at higher temperatures. This reduced ceria-based oxide is then re-oxidized either by WS or CS reaction resulting in the formation of $\mathrm{H}_{2}$ or $\mathrm{CO}$.

Ceria was first investigated for the solar thermochemical conversion of $\mathrm{H}_{2} \mathrm{O}$ into $\mathrm{H}_{2}$ by Abanades and Flamant in 2006 [32]. Rhodes et al. [33] examined ceria toward the CS reaction in more than 2000 STCs. Chueh et al. [34] analyzed the redox reactivity (RR) of ceria in 500 cycles by using a cavity-receiver reactor driven by concentrated solar power. Venstrom et al. [35] studied the isothermal operation of ceria-based thermochemical CS by performing 100 cycles. Scheffe and Steinfeld [36] thermodynamically scrutinized the application of Gd-, Y-, Sm-, Ca-, and Sr-doped ceria toward the splitting of $\mathrm{H}_{2} \mathrm{O}$ and $\mathrm{CO}_{2}$ at different temperatures and oxygen partial pressures. The $\mathrm{H}_{2}$ production capacity of the combustion synthesized $\mathrm{Cu}-, \mathrm{Ni}-, \mathrm{Mn}-$, and Fe-doped ceria via thermochemical WS reaction was estimated by Kaneko et al. [37]. Likewise, the Zr-, Sr-, Sc-, Y-, Dy-, Mg-, Hf- and Cadoped ceria were prepared and tested toward WS reaction by Meng et al. [38]. Bhosale et al. [39] developed and tested $\mathrm{Hf}^{+4}$ - and $\mathrm{Zr}^{+4}$-doped ceria toward the thermochemical CS reaction. Recently, Takalkar et al. [40, 41] examined multiple transition metals and lanthanides as the potential dopants for the ceria.

The results reported in the previous studies mainly show that the doped ceria possesses better fuel production capacity as compared to the undoped ceria. To explore further, this investigation reports the utilization of metal cations from the alkali (Li), alkaline earth $(\mathrm{Mg}, \mathrm{Ca}, \mathrm{Sr}, \mathrm{Ba})$, and post-transition $(\mathrm{Sn})$ section of the periodic table as the possible dopants for the ceria material. In previous studies [38, 42, 43], the $\mathrm{Mg}$, $\mathrm{Ca}, \mathrm{Sr}$, and Li-doped ceria materials were explored for the WS application; however, their utilization toward CS is not investigated. Furthermore, the Sndoped ceria was considered for the CS application [44]; nevertheless, the molar concentration of the dopant was 20\%. This study reports the utilization of $\mathrm{Li}-, \mathrm{Mg}-, \mathrm{Ca}-, \mathrm{Sr}-, \mathrm{Ba}-$, and $\mathrm{Sn}$-doped ceria $\left(\mathrm{Ce}_{0.9}\right.$ $\mathrm{A}_{0.1} \mathrm{O}_{2-\delta}$, where $\mathrm{A}=$ dopant) for the thermochemical splitting of $\mathrm{CO}_{2}$.

\section{Experimental section}

\section{Material preparation and characterization}

The synthesis of $\mathrm{Ce}_{0.9} \mathrm{~A}_{0.1} \mathrm{O}_{2-\delta}$ materials was carried out by using a co-precipitation of the hydroxide method. The metal nitrates and an aqueous solution of ammonium hydroxide $\left(28 \% \quad \mathrm{NH}_{4} \mathrm{OH}\right)$ were acquired from Sigma-Aldrich and utilized during the synthesis step without any pre-treatment. Deionized water was used for the dissolution of metal nitrates. Ultrapure Inert Ar (purity $=99.999 \%$ ) needed as a carrier gas, and a gas mixture containing $50 \% \mathrm{CO}_{2}$ and $50 \% \mathrm{Ar}$ (utilized as the reactive gas) were procured from Buzwair Scientific and Technical Gases, Doha, Qatar.

The dopant amounts required for the synthesis of $\mathrm{Ce}_{0.9} \mathrm{~A}_{0.1} \mathrm{O}_{2-\delta}$ materials (basis $1 \mathrm{~g}$ ) were controlled by estimating them based on the mole balance. The calculated amounts of metal nitrates were dissolved in $300 \mathrm{ml}$ of deionized water at room temperature. Once the salts were dissolved entirely in deionized water, aqueous ammonium hydroxide was added to the solution in a dropwise manner (to attain a $\mathrm{pH}$ of the solution $\sim 10$ ). The mixture was agitated for $24 \mathrm{~h}$ with a sustained $\mathrm{pH} \sim 10$. During the continuous stirring, due to precipitation, the color of the solution changes from colorless (at time $=0 \mathrm{~h}$ ) to pale yellow (at time $=24 \mathrm{~h}$ ). The next day, the stirring was stopped, and the solution obtained was kept undisturbed for $24 \mathrm{~h}$ allowing the precipitate to settle at the bottom of the beaker. The precipitated solids were recovered by decanting the supernatant liquid. The solids obtained were washed with water (using a vacuum filtration unit) to eliminate the unreacted chemicals. The solids obtained after vacuum filtration was dried at $120^{\circ} \mathrm{C}$ for $5 \mathrm{~h}$. The powder obtained after drying was crushed and annealed up to $1000{ }^{\circ} \mathrm{C}$ in the air for $4 \mathrm{~h}$. Before conducting the TGA experiments, the calcined powder of $\mathrm{Ce}_{0.9} \mathrm{~A}_{0.1} \mathrm{O}_{2-\delta}$ materials was analyzed by using the following techniques: 
a. Panalytical XPert powder X-ray diffractometer with $\mathrm{CuK} \alpha$ radiation (voltage $=45 \mathrm{kV}$, current $=20 \mathrm{~mA}, \lambda=0.15418 \mathrm{~nm}$.

b. Scanning electron microscope (SEM Nova Nano 450, FEI) equipped with energy-dispersive spectroscopy (EDS)

\section{Thermogravimetric CS experiments}

Figure 1 shows the SETSYS Evolution thermogravimetric analyzer (TGA) setup used in this investigation. The details associated with the various parts of this setup are already reported in our previous investigations [40, 41]. During the TGA experiments, the graphite heater is protected from the oxidizing gases by utilizing an inert Ar. It was also applied as a carrier gas to avoid probable vapor oxidation of the reactive sample due to gases evolved during the thermochemical reactions. The temperature of the gas streams exiting the TGA setup was controlled and maintained in a safe range by using a continuous flow of chilled water (Julabo FC 1600T). The carrier and protective Ar gas flow rates were measured and monitored continuously with the help of mass flow controllers.

As a starting point of the TGA experiments, $\sim 50 \mathrm{mg}$ of $\mathrm{Ce}_{0.9} \mathrm{~A}_{0.1} \mathrm{O}_{2-\delta}$ powder was placed inside the heating furnace with the help of a platinum $(100 \mu \mathrm{l})$ crucible. Before each thermochemical experiment, the residual air residing in the hollow space of the furnace was purged with inert Ar. The space of the furnace was then filled with a protective Ar gas with $(100 \mathrm{ml} / \mathrm{min})$. The thermal reduction (TR) of the $\mathrm{Ce}_{0.9} \mathrm{~A}_{0.1} \mathrm{O}_{2-\delta}$ materials was carried out in the presence of inert $\mathrm{Ar}$ (at $1400{ }^{\circ} \mathrm{C}$ for $60 \mathrm{~min}$ ), whereas the $\mathrm{CS}$ reaction was conducted by utilizing a gas mixture containing $50 \% \mathrm{CO}_{2}+50 \% \mathrm{Ar}\left(\right.$ at $1000{ }^{\circ} \mathrm{C}$ for $30 \mathrm{~min}$ ). Before analyzing the $\mathrm{RR}$ of the $\mathrm{Ce}_{0.9}$ $\mathrm{A}_{0.1} \mathrm{O}_{2-\delta}$ materials, a blank TGA experiment was performed by using an empty platinum crucible. The data obtained during the blank experiments were subtracted from the actual TAG experiments (performed by using the $\mathrm{Ce}_{0.9} \mathrm{~A}_{0.1} \mathrm{O}_{2-\delta}$ materials) to eliminate the thermal buoyancy effect. The mass loss $\left(\Delta m_{\text {loss }}\right)$ recorded during each TR step and the mass gain $\left(\Delta m_{\text {gain }}\right)$ observed during each CS step was attributed to the $n_{\mathrm{O}_{2}}$ released and $n_{\mathrm{CO}}$ produced by each $\mathrm{Ce}_{0.9} \mathrm{~A}_{0.1} \mathrm{O}_{2-\delta}$ material as follows:

$$
\begin{aligned}
& n_{\mathrm{O}_{2}}=\Delta m_{\text {loss }} /\left(M_{\mathrm{O}_{2}} \cdot m_{\mathrm{Ce}_{0.9} \mathrm{~A}_{0.1} \mathrm{O}_{2-\delta}}\right) \\
& n_{\mathrm{CO}}=\Delta m_{\text {gain }} /\left(M_{\mathrm{O}} \cdot m_{\mathrm{Ce}_{0.9} \mathrm{~A}_{0.1} \mathrm{O}_{2-\delta}}\right)
\end{aligned}
$$

where $M_{\mathrm{O}_{2}}=$ molecular weight of $\mathrm{O}_{2} ; M_{\mathrm{O}}=$ molecular weight of $\mathrm{O} ; \Delta m_{\text {loss }}=$ loss in the mass of $\mathrm{Ce}_{0.9}$ $\mathrm{A}_{0.1} \mathrm{O}_{2-\delta}$ recorded during the TR step; $\Delta m_{\text {gain }}=$ gain
Figure 1 SETSYS evolution TGA setup utilized to conduct the thermochemical CS experiments.

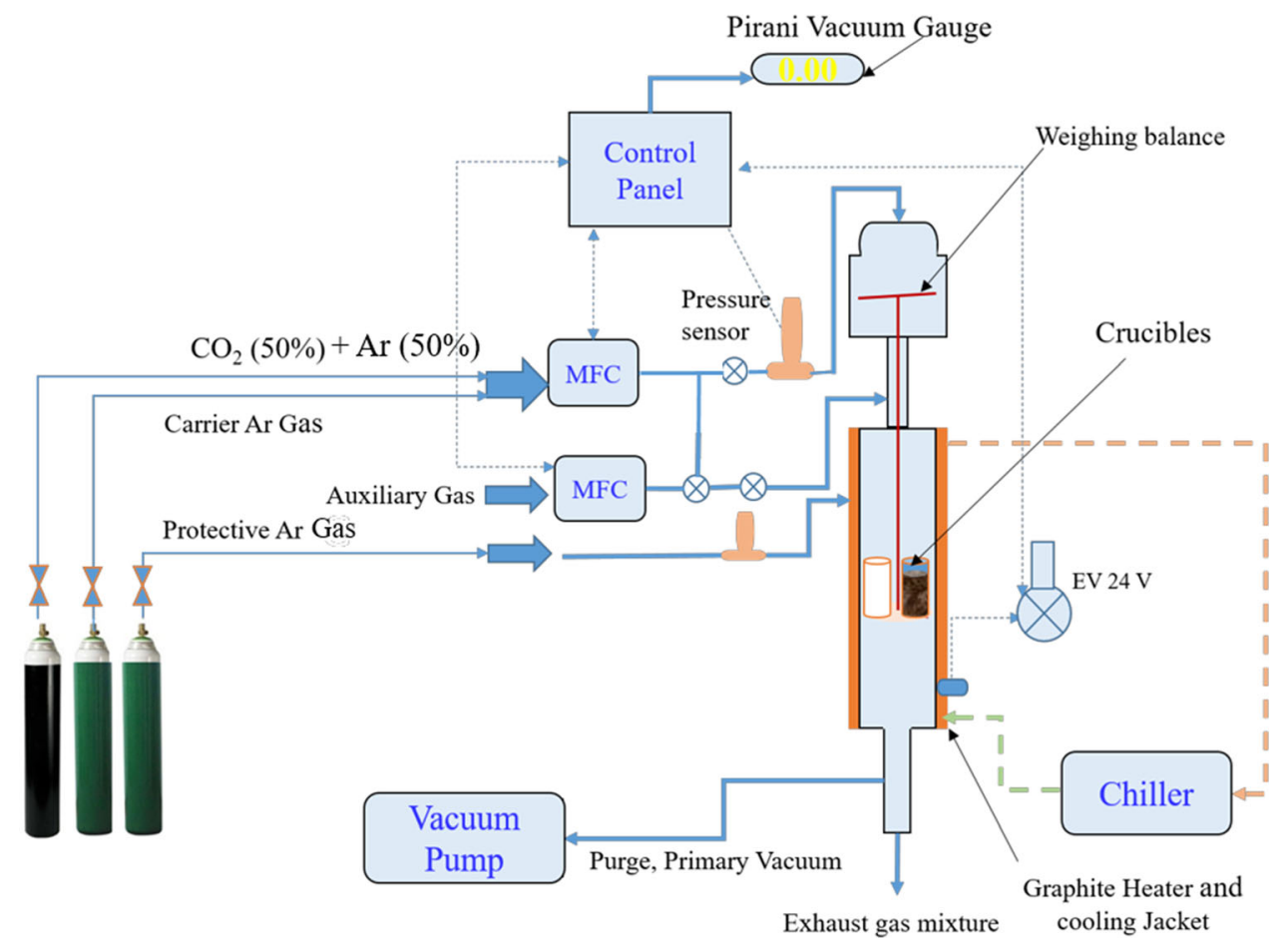


on the mass of $\mathrm{Ce}_{0.9} \mathrm{~A}_{0.1} \mathrm{O}_{2-\delta}$ recorded during the CS step; $m_{\mathrm{Ce}_{0.9} \mathrm{~A}_{0.1} \mathrm{O}_{2-\delta}}=$ total mass of $\mathrm{Ce}_{0.9} \mathrm{~A}_{0.1} \mathrm{O}_{2-\delta}$ utilized during the TGA experiments.

\section{Results and discussion}

The synthesized $\mathrm{Ce}_{0.9} \mathrm{~A}_{0.1} \mathrm{O}_{2-\delta}$ materials were characterized by using PXRD to identify their phase composition. The wide-angle $\mathrm{X}$-ray diffraction patterns of the co-precipitation synthesized $\mathrm{Ce}_{0.9} \mathrm{~A}_{0.1}$ $\mathrm{O}_{2-\delta}$ materials are presented in Fig. 2. Similar to the $\mathrm{CeO}_{2}$, the PXRD peaks of $\mathrm{Ce}_{0.9} \mathrm{~A}_{0.1} \mathrm{O}_{2-\delta}$ materials indicate sharp crystalline peaks associated with a cubic fluorite crystal. The PXRD patterns reported in Fig. 2a shows the absence of any peaks associated with the metals ( $\mathrm{Li}, \mathrm{Mg}, \mathrm{Ca}, \mathrm{Sr}, \mathrm{Ba}, \mathrm{Sn}$ ) or individual metal oxides (oxides of $\mathrm{Li}, \mathrm{Mg}, \mathrm{Ca}, \mathrm{Sr}, \mathrm{Ba}, \mathrm{Sn}$ ) impurities. The zoomed section of the PXRD $\left(2 \theta=27^{\circ}-30^{\circ}\right)$ shows a shift in the peaks for the
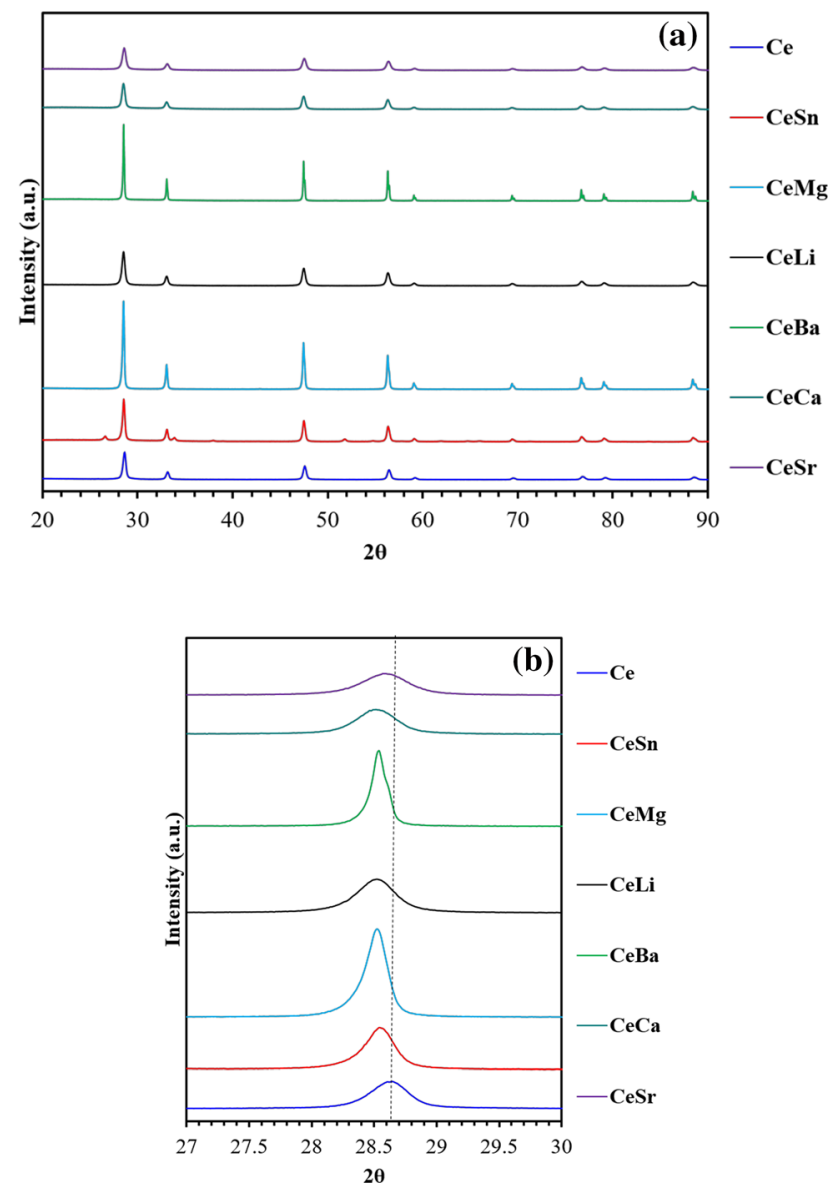

Figure 2 PXRD patterns of $\mathrm{Ce}_{0.9} \mathrm{~A}_{0.1} \mathrm{O}_{2-\delta}$ a $2 \theta=20^{\circ}-90^{\circ}$, and b $2 \theta=27^{\circ}-30^{\circ}$.
$\mathrm{Ce}_{0.9} \mathrm{~A}_{0.1} \mathrm{O}_{2-\delta}$ materials. Such peak shifts are generally attributed to the replacement of $\mathrm{Ce}^{+4}$ cation by another metal cation. Hence, from the shift in the peaks reported in Fig. $2 b$, it was evident that the $\mathrm{Li}$, $\mathrm{Mg}, \mathrm{Ca}, \mathrm{Sr}, \mathrm{Ba}$, and $\mathrm{Sn}$ are successfully incorporated in the $\mathrm{CeO}_{2}$ crystal structure. The formation of $\mathrm{Ce}_{0.9} \mathrm{~A}_{0.1} \mathrm{O}_{2-\delta}$ materials was achieved successfully via the co-precipitation of the hydroxide method.

EDS analysis was also performed to explore the elemental composition of $\mathrm{Ce}_{0.9} \mathrm{~A}_{0.1} \mathrm{O}_{2-\delta}$ materials. Exemplified EDS plots for Ba- and Sr-doped ceria are reported in Fig. 3. The comparison between the elemental compositions of the as-synthesized and calcined powders and the exact chemical composition of each $\mathrm{Ce}_{0.9} \mathrm{~A}_{0.1} \mathrm{O}_{2-\delta}$ material is listed in Table 1. The results obtained via the EDS analysis complements the findings associated with the PXRD analysis and confirms the formation of nominally phase pure $\mathrm{Ce}_{0.9} \mathrm{~A}_{0.1} \mathrm{O}_{2-\delta}$ materials.

The particle morphology of the $\mathrm{Ce}_{0.9} \mathrm{~A}_{0.1} \mathrm{O}_{2-\delta}$ materials was studied via SEM analysis. Exemplified SEM images of CeSr, CeBa, CeCa, and CeSn are presented in Fig. 4. The overall structure of all four images looks very similar, which further indicates
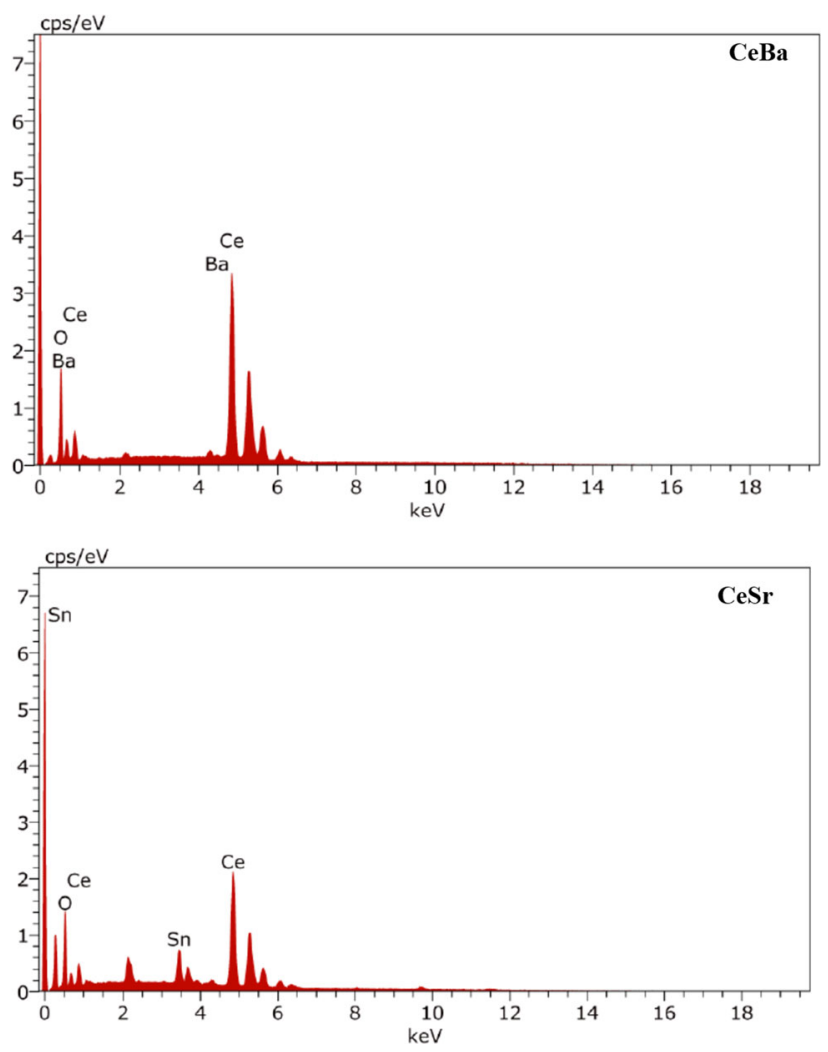

Figure 3 Exemplified EDS plots for $\mathrm{CeBa}$ and $\mathrm{CeSr}$.

\section{Springer}


Table 1 Chemical composition of $\mathrm{Ce}_{0.9} \mathrm{~A}_{0.1} \mathrm{O}_{2-\delta}$ materials: EDS analysis

\begin{tabular}{lllll}
\hline Abbreviations & $\begin{array}{l}\mathrm{Ce} / \mathrm{A} \text { ratio (as- } \\
\text { prepared) }\end{array}$ & $\begin{array}{l}\mathrm{Ce} / \text { A ratio } \\
\text { (calcined) }\end{array}$ & $\begin{array}{l}\mathrm{Ce}_{0.9} \mathrm{~A}_{0.1} \mathrm{O}_{2-\delta} \text { (chemical } \\
\text { composition) }\end{array}$ & $\begin{array}{l}\text { SEM-based Average Particle Size } \\
(\mathrm{nm})\end{array}$ \\
\hline $\mathrm{CeLi}$ & $90 / 10$ & $90.2 / 10.4$ & $\mathrm{Ce}_{0.902} \mathrm{Li}_{0.104} \mathrm{O}_{1.856}$ & 182.2 \\
$\mathrm{CeMg}$ & $90 / 10$ & $89.7 / 10.6$ & $\mathrm{Ce}_{0.897} \mathrm{Mg}_{0.106} \mathrm{O}_{1.900}$ & 171.4 \\
$\mathrm{CeCa}$ & $90 / 10$ & $89.5 / 9.9$ & $\mathrm{Ce}_{0.895} \mathrm{Ca}_{0.099} \mathrm{O}_{1.889}$ & 179.2 \\
$\mathrm{CeSr}$ & $90 / 10$ & $90.4 / 9.8$ & $\mathrm{Ce}_{0.904} \mathrm{Sr}_{0.098} \mathrm{O}_{1.906}$ & 189.9 \\
$\mathrm{CeBa}$ & $90 / 10$ & $89.7 / 10.2$ & $\mathrm{Ce}_{0.897} \mathrm{Ba}_{0.102} \mathrm{O}_{1.896}$ & 155.1 \\
$\mathrm{CeSn}$ & $90 / 10$ & $89.9 / 10.2$ & $\mathrm{Ce}_{0.899} \mathrm{Sn}_{0.102} \mathrm{O}_{2.002}$ & 163.1 \\
\hline
\end{tabular}

that the doping of different cations, i.e., $\mathrm{Li}, \mathrm{Mg}, \mathrm{Ca}$, $\mathrm{Sr}, \mathrm{Ba}$, and $\mathrm{Sn}$ does not have any significant impact on the particle morphology of $\mathrm{Ce}_{0.9} \mathrm{~A}_{0.1} \mathrm{O}_{2-\delta}$ materials. The particles are roughly spherical and seem agglomerated. The average particle size for the SEM images obtained was calculated by using the ImageJ software, and it is listed in Table 1 . As per the numbers listed, it is evident that all the $\mathrm{Ce}_{0.9} \mathrm{~A}_{0.1} \mathrm{O}_{2-\delta}$ materials have an average particle size in the range of 150-200 nm.

Characterized $\mathrm{Ce}_{0.9} \mathrm{~A}_{0.1} \mathrm{O}_{2-\delta}$ materials were tested toward thermochemical CS reactions by using a TGA setup. The variations in the mass of the samples were recorded by the Calisto software (embedded in the TGA setup). As an example, a total mass loss of
$0.260 \mathrm{mg}$ during the TR step conducted at $1400{ }^{\circ} \mathrm{C}$, and a total mass gain of $0.128 \mathrm{mg}$ during the CS step performed at $1000{ }^{\circ} \mathrm{C}$ was recorded for the CeMg material. These mass variations were converted into the $n_{\mathrm{O}_{2}}$ released $(163.0 \mu \mathrm{mol} / \mathrm{g})$ and $n_{\mathrm{CO}}$ produced $(160.0 \mu \mathrm{mol} / \mathrm{g})$ by the CeMg materials by using Eqs. (1) and (2). The ratio of $n_{\mathrm{CO}} / n_{\mathrm{O}_{2}}$ for $\mathrm{CeMg}=$ 0.981 (considerably lower than the theoretical ratio $=2$ ). A similar trend was noticed in the case of other $\mathrm{Ce}_{0.9} \mathrm{~A}_{0.1} \mathrm{O}_{2-\delta}$ materials.

A higher release of $\mathrm{O}_{2}$ during the TR step as compared to the lower production of $\mathrm{CO}$ during the CS step was unusual. As per the published literature [40, 41], the loss in the mass of reactive samples recorded during the first TR step can be attributed to
Figure 4 SEM images of a $\mathrm{CeSr}, \mathbf{b} \mathrm{CeBa}, \mathbf{c} \mathrm{CeCa}$, and d CeSn.
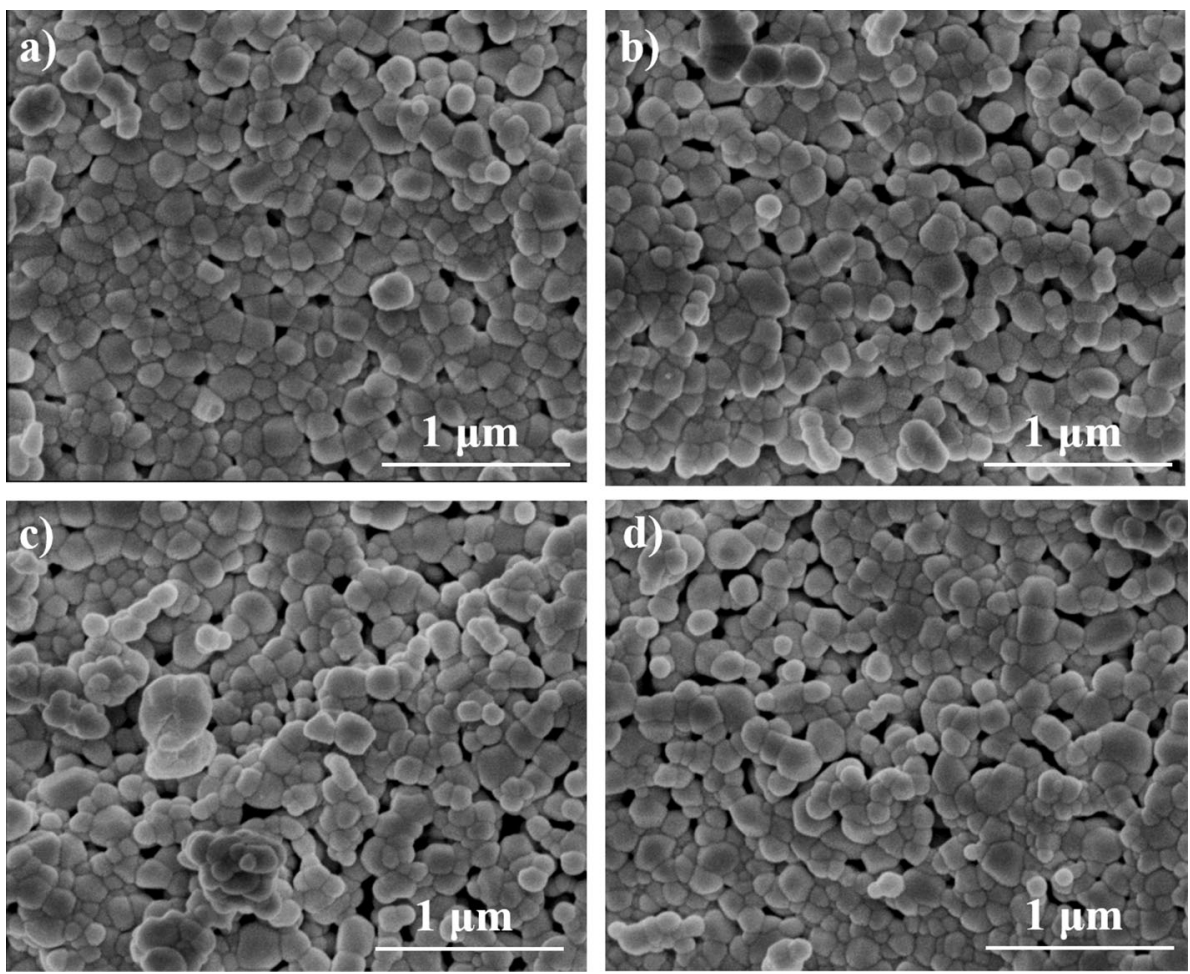
$\mathrm{O}_{2}$ release plus the release of the volatile components. Some of the chemicals used during the synthesis of the reactive samples remained unburnt during the calcination step $\left(1000{ }^{\circ} \mathrm{C}\right)$. These chemicals were burned and released from the sample during the TR step $\left(1400{ }^{\circ} \mathrm{C}\right)$. By following the results reported in the published literature [40,41], it was concluded that the $n_{\mathrm{O}_{2}}$ released by all the $\mathrm{Ce}_{0.9} \mathrm{~A}_{0.1} \mathrm{O}_{2-\delta}$ materials, calculated as per the mass loss recorded during the first TR step, was deceptive. Hence, to avoid misrepresentation, the data obtained during the first cycle were not considered hereafter.

The RR of the $\mathrm{Ce}_{0.9} \mathrm{~A}_{0.1} \mathrm{O}_{2-\delta}$ materials was examined by performing four consecutive cycles (by excluding cycle1). The variations in the mass recorded for cycle 2 to cycle 4 are presented in Fig. 5. The mass variations recorded for cycle 2 to cycle 4 were converted into the $n_{\mathrm{O}_{2}}$ released and $n_{\mathrm{CO}}$ produced and reported in Table 2. The $\mathrm{Ce}_{0.9} \mathrm{~A}_{0.1} \mathrm{O}_{2-\delta}$ materials first compared with each other based on the $n_{\mathrm{O}_{2}}$ released in each cycle. The data listed in Table 2 clearly show that the $n_{\mathrm{O}_{2}}$ released in cycle 2 by all the $\mathrm{Ce}_{0.9} \mathrm{~A}_{0.1} \mathrm{O}_{2-\delta}$ materials was higher than that of cycle 3. According to the numbers obtained, the $n_{\mathrm{O}_{2}}$ released by $\mathrm{CeLi}, \mathrm{CeMg}$, $\mathrm{CeCa}, \mathrm{CeSr}, \mathrm{CeBa}$, and $\mathrm{CeSn}$ in cycle 2 was higher by $1.4 \mu \mathrm{mol} / \mathrm{g}, 3.2 \mu \mathrm{mol} / \mathrm{g}$, $1.8 \mu \mathrm{mol} / \mathrm{g}, 1.1 \mu \mathrm{mol} / \mathrm{g}, 4.2 \mu \mathrm{mol} / \mathrm{g}$, and $0.7 \mu \mathrm{mol} / \mathrm{g}$ than cycle 3 , respectively. Likewise, the $n_{\mathrm{O}_{2}}$ released by $\mathrm{CeLi}, \mathrm{CeMg}, \mathrm{CeCa}, \mathrm{CeSr}, \mathrm{CeBa}$, and CeSn materials in cycle 4 was lower by $2.0 \mu \mathrm{mol} / \mathrm{g}, 4.1 \mu \mathrm{mol} / \mathrm{g}$, $1.7 \mu \mathrm{mol} / \mathrm{g}, 1.1 \mu \mathrm{mol} / \mathrm{g}, 2.1 \mu \mathrm{mol} / \mathrm{g}$, and $1.9 \mu \mathrm{mol} / \mathrm{g}$ as compared to cycle 3, respectively. The data reported for the CS steps have a story similar to the TR step. The CO production capacity of the CeLi,

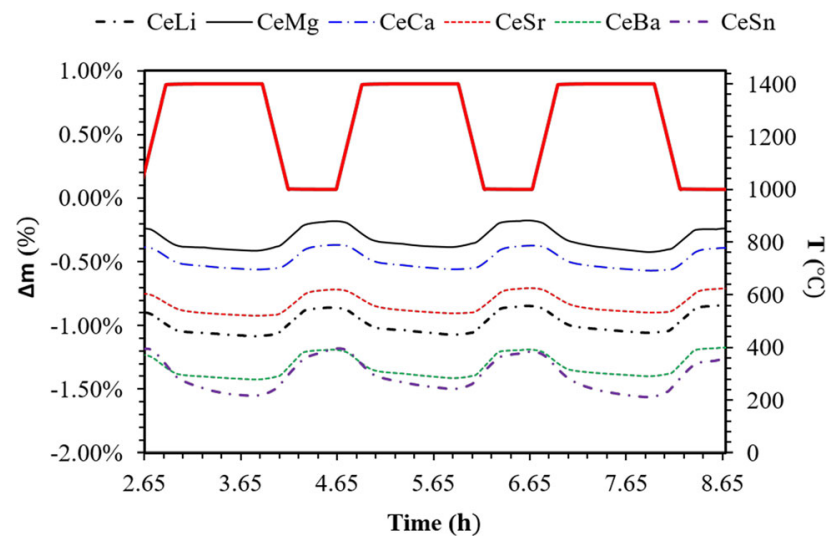

Figure 5 TGA profiles obtained for $\mathrm{Ce}_{0.9} \mathrm{~A}_{0.1} \mathrm{O}_{2-\delta}$ materials: cycle 2 to cycle 4 .
Table 2 Redox reactivity of $\mathrm{Ce}_{0.9} \mathrm{~A}_{0.1} \mathrm{O}_{2-\delta}$ materials: cycle 2 to cycle 4

\begin{tabular}{|c|c|c|c|c|c|c|}
\hline \multirow[t]{2}{*}{$\mathrm{Ce}_{0.9} \mathrm{~A}_{0.1} \mathrm{O}_{2-\delta}$} & \multicolumn{3}{|c|}{$n_{\mathrm{O}_{2}}$ released $(\mu \mathrm{mol} / \mathrm{g})$} & \multicolumn{3}{|c|}{$n_{\mathrm{CO}}$ produced $(\mu \mathrm{mol} / \mathrm{g})$} \\
\hline & TR2 & TR3 & TR4 & $\mathrm{CS} 2$ & $\mathrm{CS} 3$ & CS4 \\
\hline $\mathrm{CeLi}$ & 70.8 & 69.4 & 67.4 & 132.6 & 130.2 & 126.3 \\
\hline $\mathrm{CeMg}$ & 75.5 & 72.4 & 68.3 & 126.7 & 124.2 & 122.5 \\
\hline $\mathrm{CeCa}$ & 63.6 & 61.8 & 60.1 & 121.6 & 118.5 & 110.8 \\
\hline $\mathrm{CeSr}$ & 62.9 & 61.7 & 60.7 & 124.1 & 121.4 & 117.2 \\
\hline $\mathrm{CeBa}$ & 76.4 & 72.2 & 70.1 & 121.7 & 119.4 & 116.2 \\
\hline $\mathrm{CeSn}$ & 110.1 & 109.4 & 107.5 & 214.3 & 193.4 & 174.0 \\
\hline
\end{tabular}

$\mathrm{CeMg}, \mathrm{CeCa}, \mathrm{CeSr}, \mathrm{CeBa}$, and $\mathrm{CeSn}$ materials was decreased in cycle 4 by $4.7 \%, 3.3 \%, 8.9 \%, 5.5 \%, 4.5 \%$, and $18.8 \%$ as compared to the $\mathrm{CO}$ production realized in cycle 2 .

The results obtained in four consecutive cycles indicate that the TR and CS ability of all $\mathrm{Ce}_{0.9} \mathrm{~A}_{0.1} \mathrm{O}_{2-\delta}$ materials reduced with the rise in the number of thermochemical cycles. Performing four cycles was an initial check, and hence, a detailed analysis of the co-precipitation synthesized $\mathrm{Ce}_{0.9} \mathrm{~A}_{0.1} \mathrm{O}_{2-\delta}$ materials (at least by performing ten cycles) was essential. Therefore, the long-term RR of all the $\mathrm{Ce}_{0.9} \mathrm{~A}_{0.1} \mathrm{O}_{2-\delta}$ materials was examined by performing a set of 10 consecutive cycles. Again, to avoid the misrepresentation, the data obtained in the first cycle were not considered in this analysis. The TGA profiles obtained for all the $\mathrm{Ce}_{0.9} \mathrm{~A}_{0.1} \mathrm{O}_{2-\delta}$ materials from cycle 2 to cycle 10 are presented in Fig. 6. A close look at the TGA plots shows an indication of the attainment of stable RR by the $\mathrm{Ce}_{0.9} \mathrm{~A}_{0.1} \mathrm{O}_{2-\delta}$ materials at around cycle 4 to cycle 5 . However, a detailed comparison in terms of numbers was a must.

The $n_{\mathrm{O}_{2}}$ released by the $\mathrm{Ce}_{0.9} \mathrm{~A}_{0.1} \mathrm{O}_{2-\delta}$ materials during each thermochemical cycle is presented in Fig. 7. The data presented show that all the $\mathrm{Ce}_{0.9-}$ $\mathrm{A}_{0.1} \mathrm{O}_{2-\delta}$ materials indicate a stable release of $\mathrm{O}_{2}$ from cycle 4 to cycle 10 . For example, the $\mathrm{CeSr}$ released $60.7 \mu \mathrm{mol} / \mathrm{g}, \quad 60.1 \mu \mathrm{mol} / \mathrm{g}, \quad 60.8 \mu \mathrm{mol} / \mathrm{g}$, and $60.4 \mu \mathrm{mol} / \mathrm{g}$ of $\mathrm{O}_{2}$ in cycle 4 , cycle 6 , cycle 8 , and cycle 10. Likewise, the $\mathrm{CeMg}$ is also capable of releasing a stable amount of $\mathrm{O}_{2}$ in the range of 68.0-68.8 $\mu \mathrm{mol} / \mathrm{g}$ from cycle 4 to cycle 10 . Similar to the $\mathrm{O}_{2}$ releasing capacity, the $\mathrm{CO}$ production aptitude of all the $\mathrm{Ce}_{0.9} \mathrm{~A}_{0.1} \mathrm{O}_{2-\delta}$ materials was also noticed to be steady from cycle 4 to cycle 10 (Fig. 8). For example, CeLi produced $126.3 \mu \mathrm{mol} / \mathrm{g}, 126.0 \mu \mathrm{mol} /$ 


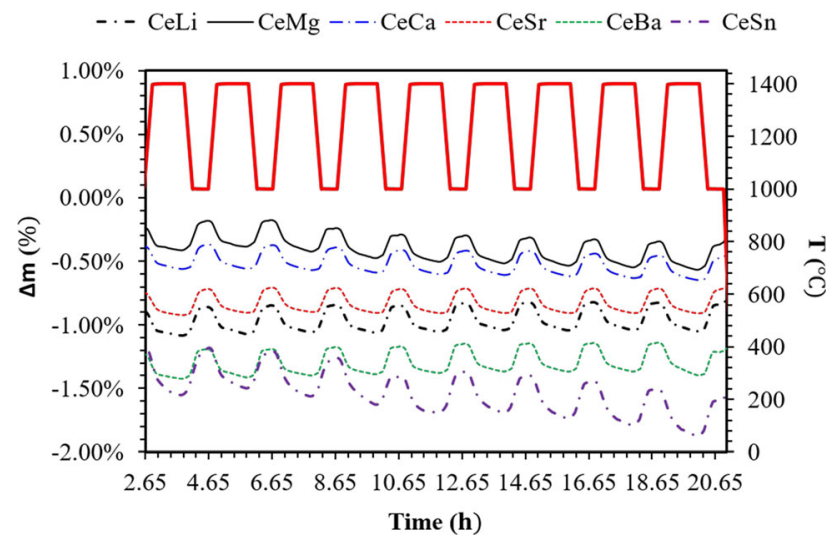

Figure 6 TGA profiles obtained for $\mathrm{Ce}_{0.9} \mathrm{~A}_{0.1} \mathrm{O}_{2-\delta}$ materials: cycle 2 to cycle 10 .

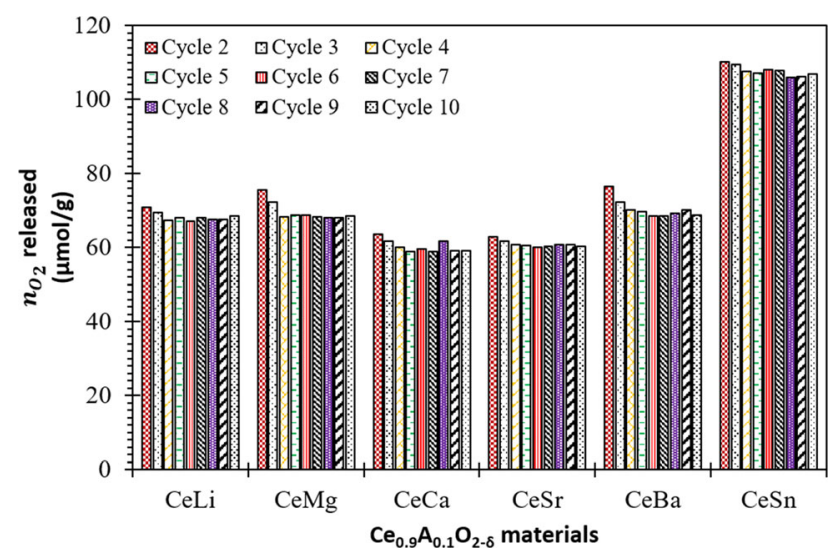

Figure $7 n_{\mathrm{O}_{2}}$ released by $\mathrm{Ce}_{0.9} \mathrm{~A}_{0.1} \mathrm{O}_{2-\delta}$ materials from cycle 2 to cycle 10 .

$\mathrm{g}, 126.6 \mu \mathrm{mol} / \mathrm{g}$, and $125.9 \mu \mathrm{mol} / \mathrm{g}$ of $\mathrm{CO}$ in cycles 4 , 6,8 , and 10 . The results obtained indicate that the initial four cycles were needed to stabilize the material properties and molecular interaction between the cations to achieve a constant $\mathrm{O}_{2}$ release and $\mathrm{CO}$ production.

Besides the interaction between the metal cations, the morphology and crystal structure also play a vital role in the stability of the redox materials. The $\mathrm{Ce}_{0.9} \mathrm{~A}_{0.1} \mathrm{O}_{2-\delta}$ materials obtained after performing the first, fifth, and tenth thermochemical cycles were characterized via SEM and PXRD. The findings acquired via PXRD analysis shows that the phase composition of all $\mathrm{Ce}_{0.9} \mathrm{~A}_{0.1} \mathrm{O}_{2-\delta}$ materials remained unaffected during multiple thermochemical cycles. The exemplified PXRD peaks for $\mathrm{CeMg}$ and $\mathrm{CeBa}$ are reported in Fig. 9a, b. The SEM analysis indicates that due to the high-temperature sintering, significant growth in the particle size of $\mathrm{Ce}_{0.9} \mathrm{~A}_{0.1} \mathrm{O}_{2-\delta}$ materials

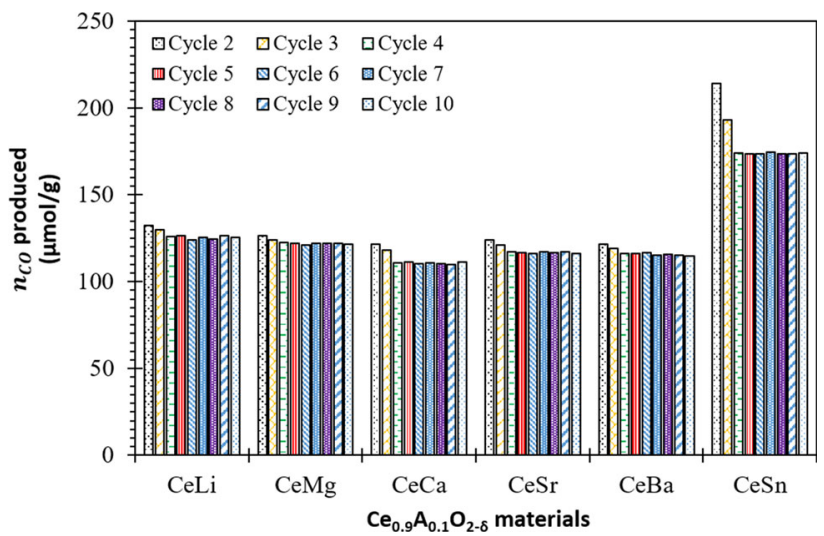

Figure $8 n_{\text {CO }}$ produced by $\mathrm{Ce}_{0.9} \mathrm{~A}_{0.1} \mathrm{O}_{2-\delta}$ materials from cycle 2 to cycle 10 .

was recorded after cycle 1 . It was also understood that the material morphology of the reacted $\mathrm{Ce}_{0.9}$ $\mathrm{A}_{0.1} \mathrm{O}_{2-\delta}$ materials obtained after cycle 5 and cycle 10 was identical to morphology observed after cycle 1 . The results obtained via SEM analysis shows that the morphology of all $\mathrm{Ce}_{0.9} \mathrm{~A}_{0.1} \mathrm{O}_{2-\delta}$ materials was
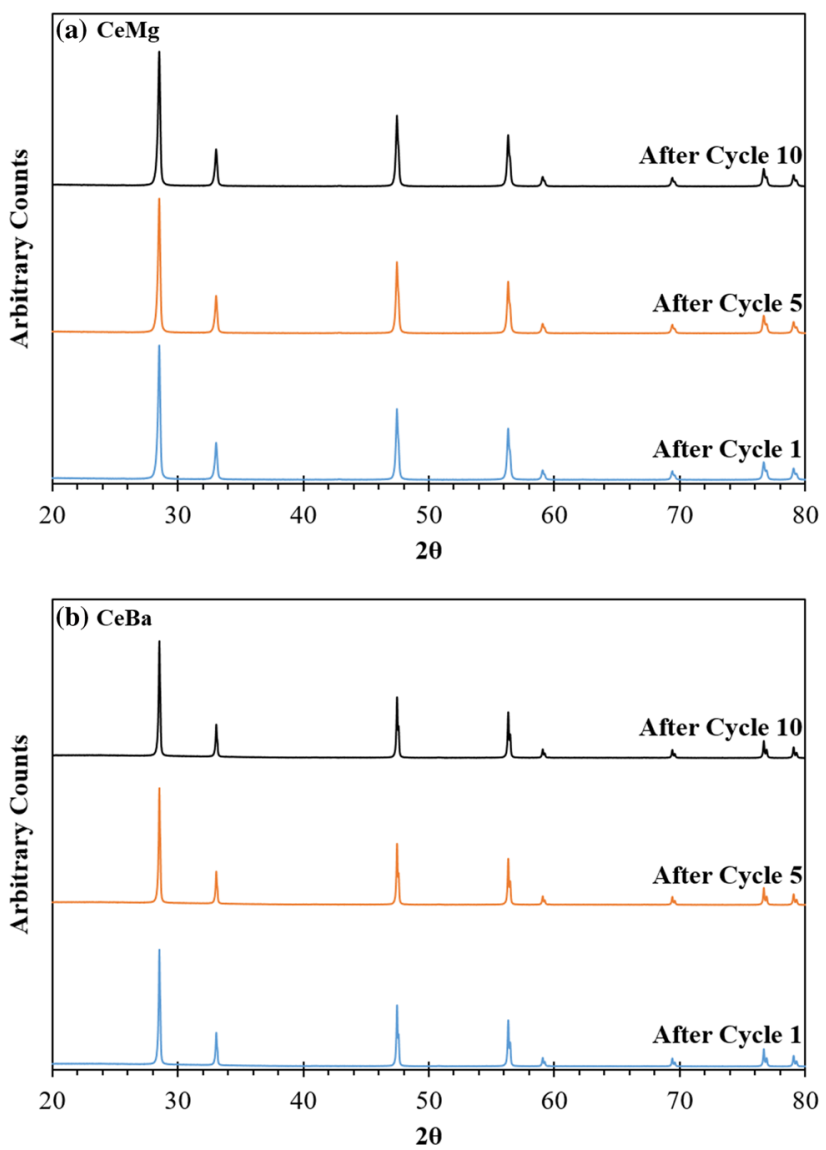

Figure 9 PXRD peaks of $\mathbf{a} \mathrm{CeMg}$ and $\mathbf{b} \mathrm{CeBa}$ obtained after performing cycle 1 , cycle 5 , and cycle 10 . 
stable from cycle 2 to cycle 10 . As an example, the SEM images for the CeMg and CeBa obtained after cycle 1, cycle 5, and cycle 10 are presented in Fig. 10a, b.

Figure 11 represents the comparison between the $\mathrm{Ce}_{0.9} \mathrm{~A}_{0.1} \mathrm{O}_{2-\delta}$ materials based on average $n_{\mathrm{O}_{2}}$ released, $n_{\mathrm{CO}}$ produced, and $n_{\mathrm{CO}} / n_{\mathrm{O}_{2}}$ ratio (from cycle 2 to cycle 10). In terms of $n_{\mathrm{O}_{2}}$ released, the $\mathrm{Ce}_{0.9} \mathrm{~A}_{0.1}$ $\mathrm{O}_{2-\delta}$ materials can be arranged as: $\mathrm{CeSn}>\mathrm{CeBa}>$ $\mathrm{CeMg}>\mathrm{CeLi}>\mathrm{CeSr}>\mathrm{CeCa}$. The average $n_{\mathrm{O}_{2}}$ released by all the $\mathrm{Ce}_{0.9} \mathrm{~A}_{0.1} \mathrm{O}_{2-\delta}$ materials was very close to each other. It was observed to be in the range of $60-70 \mu \mathrm{mol} / \mathrm{g}$ cycle, except for CeSn, for which it was considerably higher $(107.6 \mu \mathrm{mol} / \mathrm{g}$ cycle). Similar to the average $n_{\mathrm{O}_{2}}$ released, the average $n_{\mathrm{CO}}$ produced by the CeSn materials $(180.5 \mu \mathrm{mol} / \mathrm{g}$ cycle $)$ was relatively higher than the other $\mathrm{Ce}_{0.9} \mathrm{~A}_{0.1} \mathrm{O}_{2-\delta}$ materials. Based on their average $n_{\mathrm{CO}}$ production capacity, the investigated $\mathrm{Ce}_{0.9} \mathrm{~A}_{0.1} \mathrm{O}_{2-\delta}$ materials can be ranked in the following order: $\mathrm{CeSn}>\mathrm{CeLi}>$ $\mathrm{CeMg}>\mathrm{CeSr}>\mathrm{CeBa}>\mathrm{CeCa}$. Overall, as presented in Fig. 11, the incorporation of $\mathrm{Li}, \mathrm{Mg}, \mathrm{Ca}, \mathrm{Sr}, \mathrm{Ba}$, and $\mathrm{Sn}$ has considerably improved the RR of $\mathrm{Ce}_{0.9} \mathrm{~A}_{0.1}$ $\mathrm{O}_{2-\delta}$ materials as compared to the pure ceria.

The CeSn and CeCa were observed to be the top and bottom-most choices for the CS. Although the CeSn materials seem to the best choice in terms of average $n_{\mathrm{O}_{2}}$ released and $n_{\mathrm{CO}}$ produced, the average $n_{\mathrm{CO}} / n_{\mathrm{O}_{2}}$ ratio was considerably lower than most of the $\mathrm{Ce}_{0.9} \mathrm{~A}_{0.1} \mathrm{O}_{2-\delta}$ materials. As shown in Fig. 11, the $\mathrm{Ce}_{0.9} \mathrm{~A}_{0.1} \mathrm{O}_{2-\delta}$ materials can be categorized in the following order based on their re-oxidation ability:

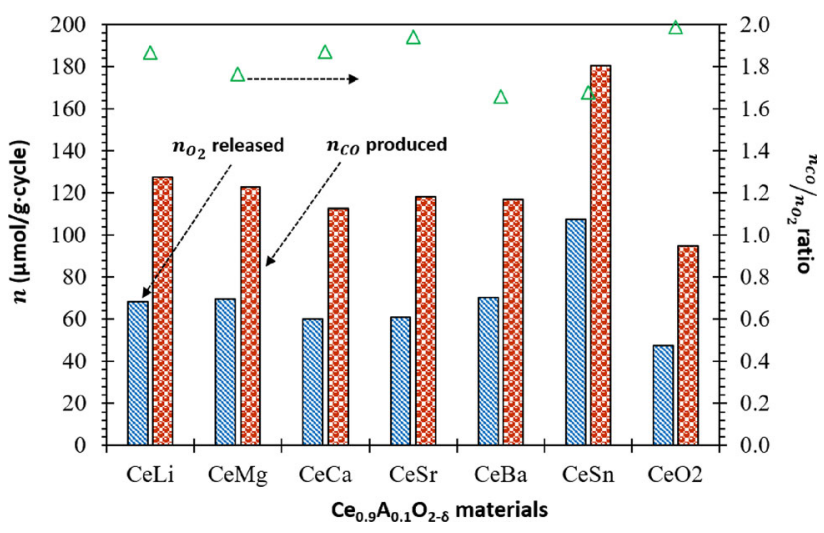

Figure 11 Comparison between the $\mathrm{Ce}_{0.9} \mathrm{~A}_{0.1} \mathrm{O}_{2-\delta}$ materials based on average $n_{\mathrm{O}_{2}}$ released, $n_{\mathrm{CO}}$ produced, and $n_{\mathrm{CO}} / n_{\mathrm{O}_{2}}$ ratio (from cycle 2 to cycle 10 ).

$\mathrm{CeSr}>\mathrm{CeLi} \sim \mathrm{CeCa}>\mathrm{CeMg}>\mathrm{CeSn}>\mathrm{CeBa}$.

These results indicate that the $\mathrm{CO}$ production ability for the CeSn can be further increased by improving the $n_{\mathrm{CO}} / n_{\mathrm{O}_{2}}$ ratio. Our research group is currently exploring the $\mathrm{Ce}_{x} \mathrm{Sn}_{1-x} \mathrm{O}_{2-\delta}$ (where $x=0.05-0.5$ ) materials to find out the best candidate for the thermochemical WS and CS.

\section{Summary and conclusions}

By applying the co-precipitation of the hydroxide method, the $\mathrm{Ce}_{0.9} \mathrm{~A}_{0.1} \mathrm{O}_{2-\delta}$ materials were synthesized by doping the alkali $(\mathrm{Li})$, alkaline earth $(\mathrm{Mg}, \mathrm{Ca}$, $\mathrm{Sr}, \mathrm{Ba}$ ), and post-transition ( $\mathrm{Sn}$ ) metal cations in the ceria cubic structure. The nominally phase pure

Figure 10 SEM images of CeMg a1 after cycle 1, a 2 after cycle 5 , a3 after cycle 10 , and $\mathrm{CeBa}-\mathbf{a} 1$ after cycle $1, \mathbf{a} 2$ after cycle 5, a3 after cycle 10 .
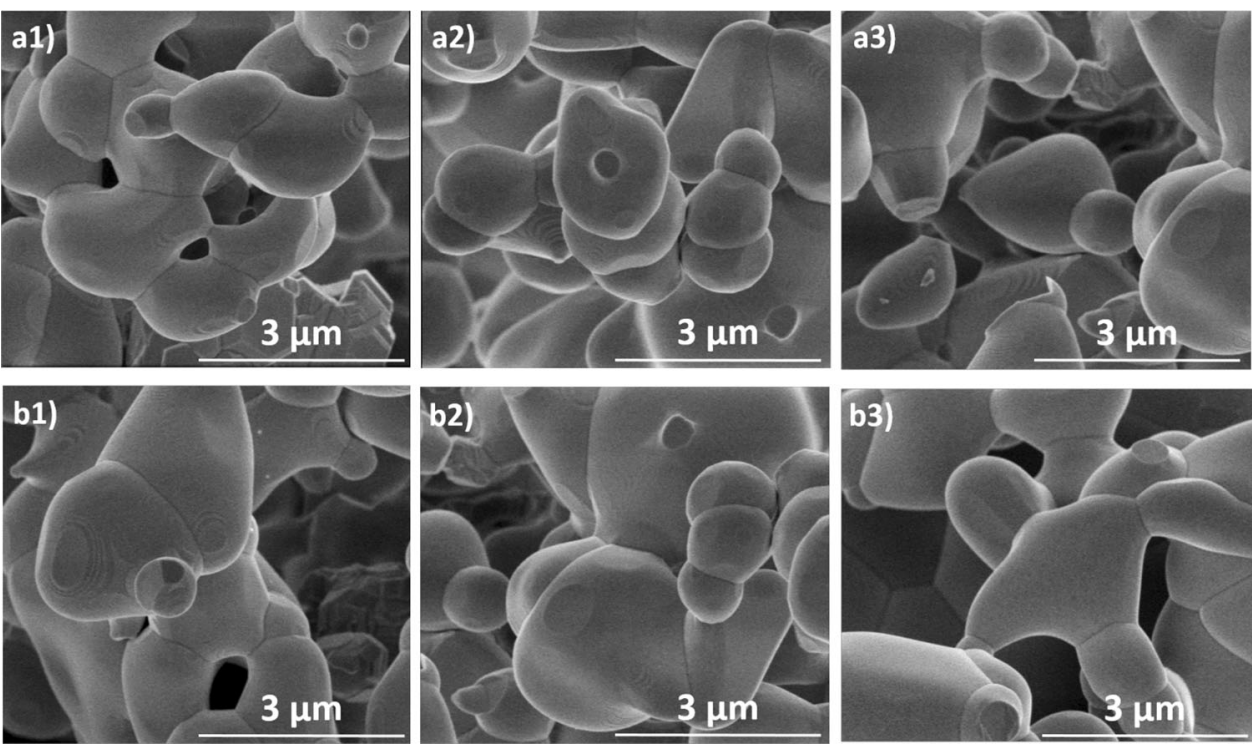
composition of each $\mathrm{Ce}_{0.9} \mathrm{~A}_{0.1} \mathrm{O}_{2-\delta}$ material was confirmed via the PXRD and EDS analysis. The SEM analysis indicates that the doping of different cations, i.e., $\mathrm{Li}, \mathrm{Mg}, \mathrm{Ca}, \mathrm{Sr}, \mathrm{Ba}$, and $\mathrm{Sn}$ does not have any significant impact on the particle morphology of $\mathrm{Ce}_{0.9} \mathrm{~A}_{0.1} \mathrm{O}_{2-\delta}$ materials (average particle size in the range of $150-200 \mathrm{~nm}$ ). The long-term $\mathrm{RR}$ of the $\mathrm{Ce}_{0.9} \mathrm{~A}_{0.1} \mathrm{O}_{2-\delta}$ materials was investigated in ten successive thermochemical cycles. The $\mathrm{O}_{2}$ releasing and $\mathrm{CO}$ production capacity of each $\mathrm{Ce}_{0.9} \mathrm{~A}_{0.1} \mathrm{O}_{2-\delta}$ material were observed to be steady from cycle 4 to cycle 10. In terms of average $n_{\mathrm{O}_{2}}$ released from cycle 2 to cycle 10, the $\mathrm{Ce}_{0.9} \mathrm{~A}_{0.1} \mathrm{O}_{2-\delta}$ materials can be arranged as: $\mathrm{CeSn}>\mathrm{CeBa}>\mathrm{CeMg}>\mathrm{CeLi}>\mathrm{CeSr}>\mathrm{CeCa}$. On the other hand, based on their average $n_{\mathrm{CO}}$ production capacity from cycle 2 to cycle 10, the investigated $\mathrm{Ce}_{0.9} \mathrm{~A}_{0.1} \mathrm{O}_{2-\delta}$ materials can be ranked in the following order: $\mathrm{CeSn}>\mathrm{CeLi}>\mathrm{CeMg}>\mathrm{CeSr}>$ $\mathrm{CeBa}>\mathrm{CeCa}$. CeSn material showed the highest $n_{\mathrm{O}_{2}}$ release $\left(107.6 \mu \mathrm{mol}\right.$ of $\mathrm{O}_{2} / \mathrm{g}$ cycle $)$ and $n_{\mathrm{CO}}$ production $(180.5 \mu \mathrm{mol}$ of $\mathrm{CO} / \mathrm{g}$ cycle) as compared to the $\mathrm{CeO}_{2}$ and the remaining $\mathrm{Ce}_{0.9} \mathrm{~A}_{0.1} \mathrm{O}_{2-\delta}$ materials.

\section{Acknowledgements}

Open Access funding provided by the Qatar National Library. This publication was made possible by the NPRP grant (NPRP8-370-2-154) from the Qatar National Research Fund (a member of Qatar Foundation). The statements made herein are solely the responsibility of author(s). The authors also gratefully acknowledge the Center of Advances Materials (CAM) at Qatar University for carrying out the XRD analysis and the Central Laboratory Unit (CLU) for services related to electron microscopy and EDS.

\section{Compliance with ethical standards}

Conflict of interest The authors declare that they have no conflict of interest.

Open Access This article is licensed under a Creative Commons Attribution 4.0 International License, which permits use, sharing, adaptation, distribution and reproduction in any medium or format, as long as you give appropriate credit to the original author(s) and the source, provide a link to the Creative Commons licence, and indicate if changes were made. The images or other third party material in this article are included in the article's Creative Commons licence, unless indicated otherwise in a credit line to the material. If material is not included in the article's Creative Commons licence and your intended use is not permitted by statutory regulation or exceeds the permitted use, you will need to obtain permission directly from the copyright holder. To view a copy of this licence, visit http://creativecommons.org/licen ses $/$ by $/ 4.0 /$.

\section{References}

[1] Acar C, Dincer I (2019) Review and evaluation of hydrogen production options for better environment. J Clean Prod 218:835-849

[2] Patil GN, Vaidya PD, Kenig EY (2011) Reaction kinetics of $\mathrm{CO} 2$ in aqueous methyl-and dimethylmonoethanolamine solutions. Ind Eng Chem Res 51:1592-1600

[3] Bhosale $\mathrm{R}$ et al (2014) $\mathrm{CO} 2$ capture using an aqueous formulated solvent containing ethylaminoethanol, N-methyl-2pyrolidone, and hydroxyl radical scavengers: study of solvent degradation and absorption kinetics. In: Proceedings of 4th annual gas processing symposium

[4] Bhosale RR, Mahajani VV (2013) Kinetics of absorption of carbon dioxide in aqueous solution of ethylaminoethanol modified with N-methyl-2-pyrolidone. Sep Sci Technol 48:2324-2337

[5] Dash SK, Samanta A, Samanta AN, Bandyopadhyay SS (2011) Absorption of carbon dioxide in piperazine activated concentrated aqueous 2-amino-2-methyl-1-propanol solvent. Chem Eng Sci 66:3223-3233

[6] Dry ME (2002) The fischer-tropsch process: 1950-2000. Catal Today 71:227-241

[7] Lu Y et al (2019) Solar fuels production: two-step thermochemical cycles with cerium-based oxides. Prog Energy Combust Sci 75:100785

[8] Steinfeld A (2005) Solar thermochemical production of hydrogen - a review. Sol Energy 78:603-615

[9] Carrillo RJ, Scheffe JR (2017) Advances and trends in redox materials for solar thermochemical fuel production. Sol Energy 156:3-20

[10] Koepf E, Alxneit I, Wieckert C, Meier A (2017) A review of high temperature solar driven reactor technology: 25 years of experience in research and development at the Paul Scherrer Institute. Appl Energy 188:620-651

[11] Bhosale RR (2018) Thermodynamic efficiency analysis of zinc oxide based solar driven thermochemical $\mathrm{H} 2 \mathrm{O}$ splitting cycle: effect of partial pressure of $\mathrm{O} 2$, thermal reduction and $\mathrm{H} 2 \mathrm{O}$ splitting temperatures. Int $\mathrm{J}$ Hydrogen Energy 43:14915-14924 
[12] Chambon M, Abanades S, Flamant G (2011) Thermal dissociation of compressed $\mathrm{ZnO}$ and $\mathrm{SnO} 2$ powders in a moving-front solar thermochemical reactor. AIChE J $57: 2264-2273$

[13] Bhosale RR, Kumar A, Sutar P (2017) Thermodynamic analysis of solar driven $\mathrm{SnO} 2 / \mathrm{SnO}$ based thermochemical water splitting cycle. Energy Convers Manag 135:226-235

[14] Stamatiou A, Loutzenhiser P, Steinfeld A (2010) Solar syngas production from $\mathrm{H} 2 \mathrm{O}$ and $\mathrm{CO} 2$ via two-step thermochemical cycles based on $\mathrm{Zn} / \mathrm{ZnO}$ and $\mathrm{FeO} / \mathrm{Fe} 3 \mathrm{O} 4$ redox reactions: kinetic analysis. Energy Fuels 24:2716-2722

[15] Scheffe JR et al (2011) Hydrogen production via chemical looping redox cycles using atomic layer deposition-synthesized iron oxide and cobalt ferrites. Chem Mater 23:2030-2038

[16] Bhosale RR et al (2019) A decade of ceria based solar thermochemical $\mathrm{H}_{2} \mathrm{O} / \mathrm{CO}_{2}$ splitting cycle. Int $\mathrm{J}$ Hydrogen Energy 44:34-60

[17] Le Gal A, Abanades S (2011) Catalytic investigation of ceria-zirconia solid solutions for solar hydrogen production. Int J Hydrogen Energy 36:4739-4748

[18] Bhosale RR et al (2014) Sol-Gel synthesis of nanocrystalline $\mathrm{Ni}$-ferrite and $\mathrm{Co}$-ferrite redox materials for thermochemical production of solar fuels. In: MRS proceedings Ser, vol 1675. Cambridge Univ Press

[19] Scheffe JR, Li J, Weimer AW (2010) A spinel ferrite/hercynite water-splitting redox cycle. Int J Hydrogen Energy 35:3333-3340

[20] Bhosale RR, Shende RV, Puszynski JA (2012) Sol-gel derived $\mathrm{NiFe} 2 \mathrm{O} 4$ modified with $\mathrm{ZrO} 2$ for hydrogen generation from solar thermochemical water-splitting reaction. In: MRS online proceedings library archive, vol 1387

[21] Agrafiotis CC et al (2012) Hydrogen production via solaraided water splitting thermochemical cycles: combustion synthesis and preliminary evaluation of spinel redox-pair materials. Int J Hydrogen Energy 37:8964-8980

[22] Shende RV, Puszynski JA, Opoku MK, Bhosale RR (2009) Synthesis of novel ferrite foam material for water-splitting application. In: Proceedings of NSTIdNanotech conference \& expo., ISBN

[23] Scheffe JR, Weibel D, Steinfeld A (2013) Lanthanumstrontium-manganese perovskites as redox materials for solar thermochemical splitting of $\mathrm{H}_{2} \mathrm{O}$ and $\mathrm{CO}_{2}$. Energy Fuels 27:4250-4257

[24] Takalkar G, Bhosale R, AlMomani F (2019) Combustion synthesized A0. 5Sr0. $5 \mathrm{MnO} 3-\delta$ perovskites (where, $\mathrm{a}=\mathrm{La}$, $\mathrm{Nd}, \mathrm{Sm}, \mathrm{Gd}, \mathrm{Tb}, \mathrm{Pr}, \mathrm{Dy}$, and $\mathrm{Y}$ ) as redox materials for thermochemical splitting of $\mathrm{CO}_{2}$. Appl Surf Sci 489:80-91

[25] Gálvez $\mathrm{M}$ et al (2015) Physico-chemical changes in $\mathrm{Ca}, \mathrm{Sr}$ and Al-doped La-Mn-O perovskites upon thermochemical splitting of CO 2 via redox cycling. Phys Chem Chem Phys 17:6629-6634

[26] Bhosale RR et al (2017) La-based perovskites as oxygenexchange redox materials for solar syngas production. MRS Adv 2:3365-3370

[27] Dey S, Naidu B, Govindaraj A, Rao C (2015) Noteworthy performance of $\mathrm{La} 1-\mathrm{x} \mathrm{Ca} \times \mathrm{MnO} 3$ perovskites in generating $\mathrm{H} 2$ and $\mathrm{CO}$ by the thermochemical splitting of $\mathrm{H} 2 \mathrm{O}$ and CO 2. Phys Chem Chem Phys 17:122-125

[28] Bhosale RR, Kumar A, AlMomani F, Ghosh U, Khraisheh M (2017) A comparative thermodynamic analysis of samarium and erbium oxide based solar thermochemical water splitting cycles. Int $\mathrm{J}$ Hydrogen Energy 42:23416-23426

[29] Bhosale $\mathrm{R}$ et al (2016) Solar hydrogen production via a samarium oxide-based thermochemical water splitting cycle. Energies 9:316

[30] Bhosale RR et al (2016) Solar hydrogen production via erbium oxide based thermochemical water splitting cycle. J Renew Sustain Energy 8:034702

[31] Bhosale R, Kumar A, AlMomani F (2016) Solar thermochemical hydrogen production via terbium oxide based redox reactions. Int J Photoenergy 2016:9727895

[32] Abanades S, Flamant G (2006) Thermochemical hydrogen production from a two-step solar-driven water-splitting cycle based on cerium oxides. Sol Energy 80:1611-1623

[33] Rhodes NR, Bobek MM, Allen KM, Hahn DW (2015) Investigation of long term reactive stability of ceria for use in solar thermochemical cycles. Energy 89:924-931

[34] Chueh WC et al (2010) High-flux solar-driven thermochemical dissociation of $\mathrm{CO}_{2}$ and $\mathrm{H}_{2} \mathrm{O}$ using nonstoichiometric ceria. Science 330:1797-1801

[35] Venstrom LJ, De Smith RM, Hao Y, Haile SM, Davidson JH (2014) Efficient splitting of $\mathrm{CO}_{2}$ in an isothermal redox cycle based on ceria. Energy Fuels 28:2732-2742

[36] Scheffe JR, Steinfeld A (2012) Thermodynamic analysis of cerium-based oxides for solar thermochemical fuel production. Energy Fuels 26:1928-1936

[37] Kaneko $\mathrm{H}$ et al (2007) Reactive ceramics of $\mathrm{CeO}_{2}-\mathrm{MO}_{\mathrm{x}}$ $(\mathrm{M}=\mathrm{Mn}, \mathrm{Fe}, \mathrm{Ni}, \mathrm{Cu})$ for $\mathrm{H}_{2}$ generation by two-step water splitting using concentrated solar thermal energy. Energy 32:656-663

[38] Meng Q, Lee C, Ishihara T, Kaneko H, Tamaura Y (2011) Reactivity of $\mathrm{CeO}_{2}$-based ceramics for solar hydrogen production via a two-step water-splitting cycle with concentrated solar energy. Int J Hydrogen Energy 36:13435-13441

[39] Bhosale RR et al (2016) Assessment of CexZryHfzO ${ }_{2}$ based oxides as potential solar thermochemical CO 2 splitting materials. Ceram Int 42:9354-9362 
[40] Takalkar G et al (2018) Transition metal doped ceria for solar thermochemical fuel production. Sol Energy 172:204-211

[41] Bhosale R, Takalkar G (2018) Nanostructured co-precipitated Ce0. 9Ln0. $1 \mathrm{O} 2$ ( $\mathrm{Ln}=\mathrm{La}, \mathrm{Pr}, \mathrm{Sm}, \mathrm{Nd}, \mathrm{Gd}, \mathrm{Tb}, \mathrm{Dy}$, or Er) for thermochemical conversion of $\mathrm{CO}_{2}$. Ceram Int 44:16688-16697

[42] Meng Q, Lee C, Shigeta S, Kaneko H, Tamaura Y (2012) Solar hydrogen production using $\mathrm{Ce}_{1-\mathrm{x}} \mathrm{Li}_{\mathrm{x}} \mathrm{O}_{2-\delta}$ solid solutions via a thermochemical, two-step water-splitting cycle. J Solid State Chem 194:343-351
[43] Le Gal A, Abanades S (2012) Dopant incorporation in ceria for enhanced water-splitting activity during solar thermochemical hydrogen generation. $\mathrm{J}$ Phys Chem C 116:13516-13523

[44] Jiang Q, Zhou G, Jiang Z, Li C (2014) Thermochemical CO2 splitting reaction with $\mathrm{CexM}_{1-\mathrm{x}} \mathrm{O}_{2-\delta}(\mathrm{M}=\mathrm{Ti} 4, \mathrm{Sn} 4, \mathrm{Hf} 4$, Zr4, La3, Y3 and Sm3) solid solutions. Sol Energy 99:55-66

Publisher's Note Springer Nature remains neutral with regard to jurisdictional claims in published maps and institutional affiliations. 